\title{
Practice of Commercial Illustration in Park Culture under Win-Win Mechanism
}

\author{
Hao Xiaohua ${ }^{1, a} \quad X u$ Jichun $^{2, b}$ Huang Yu ${ }^{3, c}$ \\ ${ }^{1}$ Guangzhou College of Technology and Business, Guangzhou, Guangdong, 510850, China \\ a 21431031@qq.com 18998313201 \\ b1105324205@qq.com 13922794396 \\ c690891965@qq.com 18022872356
}

Keywords: Applied Technology; School-enterprise Cooperation; Win-win Mechanism; Industry-teaching Integration; Artistic Design

\begin{abstract}
All applied technology universities and colleges are exploring and attempting how to carry out school-enterprise cooperative cultivation in an in-depth way. In this paper, case of running "Property Di Zi Gui Mural Project" is applied to elaborate how to cultivate applied talents in a project in which teaching is aided by practice, revealing significant effects of teaching action in the school-enterprise cooperation win-win mechanism to create an all-win situation and offering new idea for applied talent cultivation pattern.
\end{abstract}

\section{Introduction}

According to Lu Xin, Undersecretary of Ministry of Education at the 2014 China Development Forum, over 600 local universities "upgraded from junior colleges" after 2000 must change their teaching orientations to gradually transform themselves to applied universities, focus on cultivation of practical skills and develop modern vocational education. Whereas, how to make applied talent cultivation and enhance enterprise participation must be by reference to successful cases. Regarding vocational education, the most successful case on a global scale is Germany's "dual vocational education system". However, due to our national situation, enterprises are less involved in talent cultivation and school-enterprise cooperation is "superficial" instead of being "in-depth", which are common problems facing many universities and colleges at the moment. Guangzhou College of Technology and Business (hereinafter referred to as the College) adjoins Huadu of developed regional economy where enterprises seek talents with eagerness. School-enterprise cooperation has frequent interaction. As a result, many social practice projects emerge. Our department is expected to actively grasp the new opportunity to cultivate applied talents in the way of teaching practice combining projects and skills.

Wanxinda (Guangzhou) Real Estate Co., Ltd. (hereinafter referred to as the Company) is a school-enterprise cooperation organization of department of artistic design. Located in the north section of central axis of Huadu, east of Huadu Furong Road and north of Wanda Plaza--the largest real estate tourism project under construction in Asia, Furong Chunxiao Property Project has beautiful landscape and well-developed traffic. The Project is planned to cover 8 residential buildings, 900 households and $40,000 \mathrm{~m}^{2}$ of land in the park. The Company plans to build the philosophy of "family", construct the first park of "Di Zi Gui traditional Chinese culture" in China, and establish a new brand image in real estate development and property management. 


\section{Process of Project Design}

\section{Project Planning}

In order to carry forward long-standing culture and tradition of Huadu, Guangzhou, "Di Zi Gui" Mural Project was built in the Furong Chunxiao Property to show the following features:

1) Building socialist culture and ethics and constructing a cultural park in combination with construction of a beautiful country;

2) Digging connotations of local culture, promoting long-standing classical culture of Furong Town and communicating traditional Chinese culture;

3) Painting cultural relics on the wall of "Di Zi Gui", promoting brand community, creating traditional culture community and founding the first "Di Zi Gui" humane community in Guangdong Province. Constructing underground garage of property of nearly $40,000 \mathrm{~m}^{2}$ to be corridor of Di $\mathrm{Zi}$ Gui culture of thousands of meters to enable residents to be immersed in traditional culture when they come back everyday.

In mid 2015, our department negotiated with Wanxinda on the Di Zi Gui Mural Project. Both parties reached a consensus on design of the Project and founded a project design team and coordination management team. Amid summer vacation of 2015, design work was started. It took over two months to design draft, revise draft, make repeated communication, improve revision, and finalize. In November, both the College and the Company held a signing ceremony to officially initiate cooperation.

The cost of the "Di Zi Gui" Mural Project of school-enterprise cooperation was nearly RMB 70,000. After signing the contract, both the College and the Company jointly developed teaching contents. Our department organized teachers and students to elaborate scheme, regard the Project as a teaching practice project and incorporate the Project into teaching process of Commercial Illustration.

\section{Design of Project Contents}

Di Zi Gui is an important component of traditional Chinese culture and one of initiatory textbooks of children education at all times and all over the world. Its contents adopt literary contents of Article VI of "Chapter Xue Er" of Analects and list guidelines and codes which disciplines must abide by when they stay home, go out, get along with others, deal with things and study It has 360 sentences and 1,080 characters in total, with three characters in a sentence and two sentences in a rhyme, thus it reads very rhymed.

It is well-known that the original text of Di Zi Gui is simple, readable but not understandable, demanding more text interpretations. And related publications on market paraphrase Di Zi Gui in chunks of text. In order to prevent overuse of text and increase picture sophistication, it is advised to design a way of short stories and simple conversations to interpret the classics. In line with the creation standard of 4 sentences in combination with one picture for Di Zi Gui together with 8 themes, a total of 98 works must be designed. The design team completed draft of each section by division of labor and teamwork.

\section{Computer Painting and Making}

The course of Commercial Illustration is a core course of artistic design in which tasking instruction was carried out by being centered on "Di Zi Gui" enterprise practice project. The team of teachers and students started scanning manuscripts, delineating and coloring by computer design software after getting preliminary sketches. Since works were created by different teachers and students, images of characters must be unified. The Project Group completed design of characters in a family first of all: design of images of elders, parents, brothers, sisters and other characters and deduced each illustration story by such images. Of 40 students, each student completed recreating contents of 2-3 pictures. A teacher led some excellent students to check, modify and improve each 
work in line with the standard. In the end, the collection of works of Di Zi Gui was completed. The collection was mobilized when appropriate after being examined and approved by general manager of the enterprise.

The underground garage of the property has area of nearly 30,000 $\mathrm{m} 2$ and height of 4 at the construction site. After survey, each picture was designed to be $2.5 \times 1.5 \mathrm{~m}$. The Project Group assigned intern students to station at the site, calculate full length of walls of garage, distribute positions for 98 pictures, leave gaps and position each picture. According to size of pictures, the Project Group purchased acrylic paint in Huanghsa, Guangzhou to prepare for construction.

\section{Site Construction Process of Project}

\section{Site Construction and Management}

At the end of November 2015, the team of teachers and students was mobilized for construction. After frequent negotiation, the College and the Company made division of labor and teamwork in which the Company provided convenient accommodation, transport and catering and specially assigned someone to track and coordinate at the site; the College well coordinated in details of site construction and assign two intern students to station at the construction site for preliminary work, mainly completion of mural position distribution, projection positioning, pencil delineating, and unified allocation of colors for standby application. On weekends, teachers led 10-20 students to delineate and color at the site. Due to appropriate method and full-time and part-time combination, students felt very exited that their works could be presented on walls. The Project made smooth progress. Over 90 people were organized to paint in succession in over 1 month's time. The progress and effects of the Project were recognized by Party A as well. The Company frequently led house purchase customers to pay a visit to the site in construction, boosting sales of the property.

\section{Project Finishing and Completion}

Prior to the winter vacation of 2015, the main painting work was already completed. Earlier in the spring of 2016 when temperature and humidity started to rise and weather got better in Guangzhou, the Project Group stepped up completing construction and fabrication of more than 80 manhole covers in the park. On the basis of elements of $\mathrm{Di} \mathrm{Zi}$ Gui, the contents made were completed. Outdoors and rainy season resulted in some effects on air drying of pigments. The design team made repeated test to ultimately solve fading, insecurity and other problems. As a result, the Project was completed in the end. In April 2016, the College and the Company held a grand completion ceremony at Furong Chunxiao Property and commended those excellent students in practice.

So far, the whole park site takes on a completely new look after the follow-up work of epoxy floor paint of underground garage of property is completed. The traditional Chinese culture of Di Zi Gui in the park of the property has become an important selling point and all units have been sold out. A win-win situation has been created.

\section{Summary of Di Zi Gui Project}

The school-enterprise cooperation project fully reflects effects of the "win-win mechanism" in project-oriented teaching process, teachers' teaching design, students' practical capacity, practices "going to society" and shows the important role of enterprise project practice in applied talent cultivation. It boosts sales of the property as well. It creates an all-win situation.

1. Improvement of professional talent cultivation pattern: many ability cultivation goals have been completed according to ability demands of positions.

2. Boost of progress of students by practical teaching: practical project and ability training are important exercises for operational abilities of students.

3. Boost of teachers of teaching qualification and occupational qualification by enterprise practice: teachers get opportunities of enterprise practice while teaching.

4. School-enterprise cooperative cultivation aimed at win-win mechanism: the College and the 
Company jointly develop courses and contents and set standards, test quality of talent cultivation and project completion and realize the aim of collaborative innovation.

\section{Conclusion}

Concerning teaching practice in the win-win mechanism by school-enterprise cooperation, highly practical courses of commercial illustration greatly enhance participation and learning interest of students and transform from "wanted to learn" to "want to learn". Many students have spent their spare time in practice to follow their instructors to exchange time for works and skills. It highlights cultivation effects of teaching pattern in the win-win mechanism by school-enterprise cooperation on students. Therefore, it is necessary to put collaborative cultivation by school-enterprise cooperation in an important position in applied teaching reform of universities and colleges to cultivate down-to-earth applied talents.

\section{Acknowledgements}

Guangdong Higher Vocational and Technical Education Research Society 2014 Project (GDGZ14 Y172)

About the Author: Hao Xiaohua (1969-), male, master of arts, from Shandong, associate professor of Guangzhou College of Technology and Business, mainly engaged in studies on artistic design.

\section{References}

[1] You Meiqin. Win-win mechanism by school-enterprise cooperation and professional development of faculty of vocational colleges [J]. Expo of Teachers (Science and Research Edition). May 20, 2014.

[2] Cai Feng; Wang Gongming. Exploration for talent cultivation pattern in win-win mechanism by school-enterprise cooperation for arts and crafts [J]. Art Education Research. August 15, 2013.

[3] Yi Bin. Exploration for introduction of pattern of win-win mechanism by school-enterprise cooperation to vocational education of architecture [J]. Guangxi Education. December 20, 2014. 